Old Dominion University

ODU Digital Commons

OEAS Faculty Publications

Ocean, Earth \& Atmospheric Sciences

1988

\title{
Consequences of Thymidine Catabolism for Estimates of Bacterial Production: An Example from a Coastal Marine Sediment
}

\author{
Kevin R. Carman \\ Fred C. Dobbs \\ Old Dominion University, fdobbs@odu.edu \\ James B. Guckert
}

Follow this and additional works at: https://digitalcommons.odu.edu/oeas_fac_pubs

Part of the Marine Biology Commons, and the Oceanography Commons

\section{Repository Citation}

Carman, Kevin R.; Dobbs, Fred C.; and Guckert, James B., "Consequences of Thymidine Catabolism for Estimates of Bacterial Production: An Example from a Coastal Marine Sediment" (1988). OEAS Faculty Publications. 143.

https://digitalcommons.odu.edu/oeas_fac_pubs/143

\section{Original Publication Citation}

Carman, K. R., Dobbs, F. C., \& Guckert, J. B. (1988). Consequences of thymidine catabolism for estimates of bacterial production: An example from a coastal marine sediment. Limnology and Oceanography, 33(6), 1595-1606. doi: 10.4319/lo.1988.33.6part2.1595

This Article is brought to you for free and open access by the Ocean, Earth \& Atmospheric Sciences at ODU Digital Commons. It has been accepted for inclusion in OEAS Faculty Publications by an authorized administrator of ODU Digital Commons. For more information, please contact digitalcommons@odu.edu. 
1984. Concentration and preliminary characterization of a chemical attractant of the oyster drill, Urosalpinx cinerea. J. Chem. Ecol. 10: 63-79.

Rosenthal, G. A., AND D. H. JANzEN. 1979. Herbivores: Their interaction with secondary plant metabolites. Academic.

RothSCHILD, M. 1973. Secondary plant substances and warning coloration in insects. R. Entomol. Soc. Lond. Symp. 6: 59-83.

Sainte-Marie, B., AND B. T. Hargrave. 1987. Estimation of scavenger abundance and distance of attraction to bait. Mar. Biol. 94: 431-443.

Sjoblad, R. D., I. Chet, and R. Mitchell. 1978. Chemoreception in the green alga Dunaliella tertiololecta. Curr. Top. Microbiol. Immunol. 1:305307.

Smart, P. L., AND I. M. S. Laidlaw. 1977. An evaluation of some fluorescent dyes for water tracing. Water Resour. Res. 13: 15-33.

Snow, J. W., I. B. Mackay, B. E. Paton, And A. W. Herman. 1986. Fibre optic remote sensing for in situ measurement of marine optical properties, p. 482-485. In Oceans '86. Conf. Record V. 2. IEEE.

Stanley, B. H., H. E. Hummel, and W. G. Ruesink. 1985. Estimating maximum horizontal area of pheromone plumes. J. Chem. Ecol. 11: 1129-1 146.

WRIGHT, R. H. 1958. The olfactory guidance of flying insects. Can. Entomol. 90: 81-89.

ZIMMER-FAUST, R. K. 1987 . Crustac an chemical perception: Towards a theory or optimal chemoreception. Biol. Bull. 172: 10-29.

, AND J. F. CASE. 1983. A proposed dual role of odor in foraging by the California spiny lobster, Panulirus interruptus (Randall). Biol. Bull. 164: 341-353.

, J. E. Tyre, W. C. Michel, and J. F. CASE. 1984. Chemical mediation of appetitive feeding in a marine decapod crustacean: The importance of suppression and synergism. Biol. Bull. 167: 339_ 353.

Submitted: 21 March 1988 Accepted: 9 June 1988 Revised: 23 August 1988

\section{Consequences of thymidine catabolism for estimates of bacterial production: An example from a coastal marine sediment}

\begin{abstract}
Radioactively labeled thymidine (TdR) has been used extensively to measure bacterial production in aquatic environments, but critical assumptions of the TdR technique often have gone untested. In this study of a coastal marine sediment, the metabolic fate of methyl $\left[{ }^{3} \mathrm{H}\right] \mathrm{TdR}$ and methyl $\left[{ }^{14} \mathrm{C}\right] \mathrm{TdR}$ was at variance with the assumptions necessary for determining bacterial production. Only $2 \%$ of incorporated radioactivity was recovered in the DNA fraction of TCA-insoluble material following time-course incubations of 1-300 min. At least the methyl group of TdR was extensively catabolized, as shown by copious production of ${ }^{14} \mathrm{CO}_{2}$. The temporal patterns of ${ }^{3} \mathrm{H}:{ }^{14} \mathrm{C}$ ratios in macromolecu-
\end{abstract}

\section{Acknowledgments}

We thank P. LaRock for helpful discussions and use of his laboratory, M. Foy for assistance with the experiment, and D. Karl for advice on technical aspects of DNA extraction. K. Hofer and M. Schneiderman provided comments on our results. The manuscript was improved by comments from $\mathbf{R}$. Iverson, $\mathrm{P}$. LaRock, D. Thistle, and three reviewers.

This research is Florida State University Marine Laboratory Contribution No. 1046 and was funded in part by Sigma Xi Grants-in-Aid-of Research (F.C.D. and K.R.C.) and NSF Grant OCE 83-09967 (P. A. LaRock).

\begin{abstract}
lar fractions indicated that products of catabolism were recycled into the DNA fraction. The accuracy of the TdR technique depends in large part on the degree to which such catabolism occurs.
\end{abstract}

Estimation of bacterial production in aquatic environments is of interest to $\mathrm{mi}-$ crobial ecologists, organic geochemists, limnologists, and oceanographers, among others. There has been a recent proliferation of such estimates, accompanied by controversy regarding the technique of choice (e.g. Hagström et al. 1979; Karl 1986; Moriarty 1986; Fuhrman et al. 1986; Karl and Winn 1986). Many investigators use radiolabeled precursors of nucleic acids and, for example, incorporation of radioactivity into deoxyribonucleic acid (DNA) as a measure of bacterial growth. Undoubtedly the most popular precursor has been the nucleoside thymidine (thymidine deoxyribose, hereafter TdR); methyl $\left[{ }^{3} \mathrm{H}\right] \mathrm{TdR}$ is the most frequently used form. The expectation has been 
that TdR in natural samples is incorporated specifically and directly into DNA of heterotrophic bacteria over incubation times ranging from minutes to hours (Fuhrman and Azam 1980, 1982; Moriarty and Pollard 1981; Pollard and Moriarty 1984).

Several assumptions are associated with estimating bacterial production in nature with the TdR technique (Brock 1971; Karl 1986; Moriarty 1986). Incorporation of label must be linear with time and due only to bacterial uptake of TdR. Radioactivity in DNA must result from direct incorporation of labeled TdR, not from recycling of degradation products of catabolized TdR. If production is estimated by radioassaying unfractionated, acid-insoluble material, one must assume that radioactivity is not present in acid-insoluble macromolecules other than DNA. Violation of any of these assumptions would decrease the accuracy of the production estimate.

Previous studies indicate that radioactivity from labeled TdR may be incorporated into TCA-insoluble macromolecules other than DNA (i.e. RNA, protein, and possibly lipids) (e.g. Riemann et al. 1982; Findlay et al. 1984; Robarts et al. 1986; Hollibaugh 1988); this phenomenon has been referred to as "nonspecific labeling" (Karl 1982; Moriarty 1986). We became interested in the degree and extent of nonspecific labeling while investigating the utility of methyl $\left[{ }^{3} \mathrm{H}\right] \mathrm{TdR}$ as a tracer of bacterial grazing by meiofauna in marine sediment (Dobbs et al. in prep.). We observed that after a 5-h incubation more ${ }^{3} \mathrm{H}$ was incorporated into nonpolar lipids than into DNA. These observations formed the impetus for the present study, in which we conducted a more thorough investigation of the fate of labeled $\mathrm{TdR}$ in a coastal marine sediment. We used a mixture of methyl $\left[{ }^{3} \mathrm{H}\right] \mathrm{TdR}$ and methyl $\left[{ }^{14} \mathrm{C}\right] \mathrm{TdR}$ to determine the extent and temporal pattern of catabolism of TdR and nonspecific labeling of macromolecules. This dual-label approach also provided evidence that radioactivity appeared in DNA and other macromolecules via recycling of label from catabolized TdR, even after very brief incubations.

On 22 June 1987, we hand-collected 27 cores of intertidal marine sediment using $2.1-\mathrm{cm}$-i.d., 10-cm-long, plastic core liners.
Sediment at the study site $(500 \mathrm{~m}$ west of the F.S.U. Marine Laboratory; $29^{\circ} 55.00^{\prime \prime} \mathrm{N}$, $84^{\circ} 30.36^{\prime \prime} \mathrm{W}$ ) is a medium-fine quartz sand. A distinct transition from light- to darkcolored sediment indicated that approximately the top $0.5 \mathrm{~cm}$ of sediment was oxidized. Silt-clay and organic content of the sand were each $<1 \%$ by weight. About 2 $\mathrm{cm}$ of water overlay the sediment at collection. Cores were placed in an insulated container filled with seawater (to maintain ambient temperature) and transported to the laboratory. Incubations were started within $2 \mathrm{~h}$ of collection.

Radioisotopes were used shortly after purchase (Research Products Int. Corp.). Immediately before use, radiolabels were dried under a stream of nitrogen and reconstituted in filtered $(0.2 \mu \mathrm{m})$ seawater. After reconstitution, total $\mu \mathrm{Ci} \mathrm{ml^{-1 }}$ were determined separately for $\left[{ }^{3} \mathrm{H}\right] \mathrm{TdR}$ and $\left[{ }^{14} \mathrm{C}\right] \mathrm{TdR}$. The isotopes were then mixed and total $\mu \mathrm{Ci} \mathrm{ml} l^{-1}$ for ${ }^{3} \mathrm{H}$ and ${ }^{14} \mathrm{C}$ were determined simultaneously with a dual-label program (discussed below). A mixture of $9.02 \mu \mathrm{Ci}$ of methyl $\left[{ }^{3} \mathrm{H}\right] \mathrm{TdR}\left(43 \mathrm{Ci} \mathrm{mmol}^{-1}\right)$ and $1.97 \mu \mathrm{Ci}$ of methyl $\left[{ }^{14} \mathrm{C}\right] \mathrm{TdR}(50 \mathrm{mCi}$ $\mathrm{mmol}^{-1}$ ) was injected horizontally $2 \mathrm{~mm}$ below the sediment surface of the cores (Findlay et al. 1985) with a 50- $\mu$ l syringe (Hamilton Co.). The ratio of radioactivity $\left(\mu \mathrm{Ci}{ }^{3} \mathrm{H}: \mu \mathrm{Ci}{ }^{14} \mathrm{C}\right)$ added to cores was 4.58 . Cores were incubated for $1,10,30,60,180$, and $300 \mathrm{~min}$ after injection of isotopes. Cores were incubated in the dark to prevent photosynthetic fixation of any potential respired ${ }^{14} \mathrm{CO}_{2}$. (Dark fixation of ${ }^{14} \mathrm{CO}_{2}$ in the top $1 \mathrm{~cm}$ of this sediment is negligible: Carman pers. obs.; therefore fixation of respired ${ }^{14} \mathrm{CO}_{2}$ by chemoautotrophic bacteria was assumed to be unimportant.) Three replicate cores were used for each incubation period.

At the end of an incubation period, the water overlying the sediment was removed, its volume measured (Fig.1), and a 4-ml subsample was taken to determine its ${ }^{14} \mathrm{CO}_{2}$ content (Hobbie and Crawford 1969; Iverson et al. 1976). Because only ${ }^{14} \mathrm{CO}_{2}$ that had diffused from sediments into the overlying water was measured, ${ }^{14} \mathrm{CO}_{2}$ data should be considered as a minimum and delayed estimate of respired TdR. Next, the top 1 $\mathrm{cm}$ of sediment was extruded, homoge- 


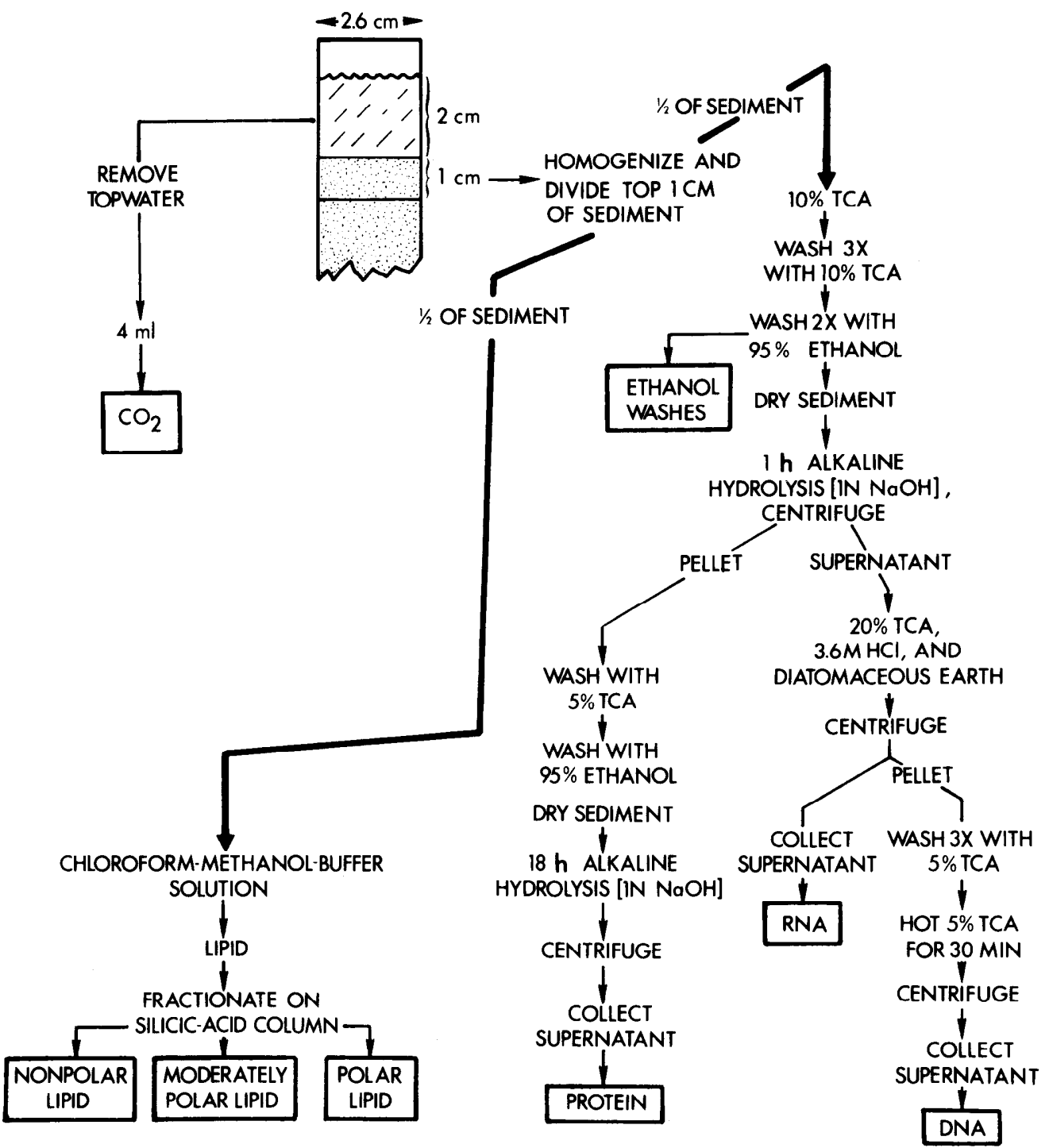

Fig. 1. Procedure used to analyze sediment cores injected with methyl $\left[{ }^{3} \mathrm{H}\right] \mathrm{TdR}$ and methyl $\left[{ }^{14} \mathrm{C}\right] \mathrm{TdR}$. Components that were radioassayed are enclosed in boxes. Further details are provided in the text.

nized, and divided approximately in half. Half of the sediment was placed in ice-cold $10 \%$ TCA. DNA and RNA fractions were extracted from acid-insoluble material according to the type 2 procedure of Craven and Karl (1984) for noncarbonate sands. The Craven and Karl procedure includes two ethanol washes of TCA-insoluble material before separation of macromolecular fractions. These ethanol washes were also radioassayed.

After removing RNA and DNA fractions, the protein fraction was separated from the sediment pellet with a modification for sediments of Karl's (1982) method for filters. Specifically, the pellet was washed twice with ice-cold 5\% TCA and twice with ice-cold $95 \%$ ethanol, then dried. Ten milliliters of $1 \mathrm{~N} \mathrm{NaOH}$ were added to the pellet, which was held for $18 \mathrm{~h}$ in a water-bath shaker at $37^{\circ} \mathrm{C}$. The material was vortexed several times during hydrolysis. Afterward, the material was centrifuged for $10 \mathrm{~min}$ at 1,800 $\times g$ and the supernatant radioassayed.

The other half of the sediment was placed in a chloroform-methanol solution, and lip- 
Table 1. Control experiments. Radioactivity recovered in macromolecular fractions from formaldehydekilled sediments incubated for 1 and $300 \mathrm{~min}$, and extraction controls (see text for details). EtOH wash-ethanol wash. Values represent the mean (SD) of three replicates. Data are expressed as dpm $\mathrm{gdw}^{-1}$.

\begin{tabular}{|c|c|c|c|c|c|c|}
\hline & \multicolumn{4}{|c|}{ Formaldehyde killed (min incubated) } & & \\
\hline & \multicolumn{2}{|c|}{1} & \multicolumn{2}{|l|}{300} & \multicolumn{2}{|c|}{ Extraction control } \\
\hline & ${ }^{3} \mathrm{H}$ & ${ }^{14} \mathrm{C}$ & ${ }^{3} \mathrm{H}$ & ${ }^{14} \mathrm{C}$ & ${ }^{3} \mathrm{H}$ & ${ }^{14} \mathrm{C}$ \\
\hline \multicolumn{7}{|c|}{ Fractions of TCA-insoluble material } \\
\hline $\begin{array}{l}\text { DNA } \\
\text { RNA } \\
\text { Protein } \\
\text { EtOH wash }\end{array}$ & $\begin{array}{c}0^{*} \\
366(276) \\
113(178) \\
615(527)\end{array}$ & $\begin{array}{c}0 \\
60(33) \\
2(20) \\
131(118)\end{array}$ & $\begin{array}{c}0 \\
474(124) \\
177(115) \\
676(112)\end{array}$ & $\begin{array}{c}0 \\
86(28) \\
23(6) \\
174(32)\end{array}$ & $\begin{array}{c}0 \\
683(69) \\
0 \\
2,238(594)\end{array}$ & $\begin{array}{c}0 \\
97(15) \\
0 \\
495(137)\end{array}$ \\
\hline \multicolumn{7}{|l|}{ Lipids } \\
\hline $\begin{array}{l}\text { Nonpolar } \\
\text { Moderately polar } \\
\text { Polar }\end{array}$ & $\begin{array}{c}7(7) \\
5,822(6,363) \\
229(205)\end{array}$ & $\begin{array}{c}0 \\
1,273(1,438) \\
48(63)\end{array}$ & $\begin{array}{c}4(2) \\
4,130(3,829) \\
225(175)\end{array}$ & $\begin{array}{c}0 \\
910(865) \\
49(37)\end{array}$ & $\begin{array}{c}34(12) \\
42,669(6,758) \\
1,447(235)\end{array}$ & $\begin{array}{c}7(4) \\
9,449(1,481) \\
316(110)\end{array}$ \\
\hline $\mathrm{CO}$ & - & $294(83)$ & - & $302(140)$ & - & - \\
\hline
\end{tabular}

* Raw dpm (i.e. unadjusted for subsampling and weight of sediment) $<10$ were considered 0 (SD not calculated).

ids were extracted according to the method of White et al. (1979). Bulk lipids were separated into nonpolar (neutral), moderately polar (glyco-), and polar (phospho-) lipid fractions (Guckert et al. 1985) with prepacked, 3-ml, 500-mg silicic-acid columns (Thomas Scientific).

Radioactivity was quantified with a duallabel program on an LKB Wallac liquidscintillation counter (model 1217). Background counts were subtracted from sample counts before counts per minute $(\mathrm{cpm})$ were converted to disintegrations per minute $(\mathrm{dpm})$ by the method of external standardschannels ratio. Ethanol washes of TCA-insoluble material and lipid fractions were bleached with light to reduce color quenching and evaporated under a stream of nitrogen before adding $10 \mathrm{ml}$ of Handifluor (Mallinckrodt). Handifluor was also used as a scintillation cocktail for the radioassay of ${ }^{14} \mathrm{CO}_{2}$. Protein was radioassayed by adding $10 \mathrm{ml}$ of Hionicfluor (Packard Instr. Co.) to $1 \mathrm{ml}$ of protein extract. DNA and RNA were radioassayed by adding $10 \mathrm{ml}$ of Picofluor (Packard Instr. Co.) to $1 \mathrm{ml}$ of extract.

The reliability of the dual-label program was tested with a mixture of ${ }^{3} \mathrm{H}$ and ${ }^{14} \mathrm{C}$ $\left({ }^{3} \mathrm{H}:{ }^{14} \mathrm{C}\right.$ ratio $\left.=4.58\right)$ at dilutions that encompassed the dpm measured in experimental samples. The dual-label program yielded ratios accurate to within $6 \%$ of expected ratios $(4.58)$ at levels comparable to radioactivity present in most of our samples (i.e. $400-40,000 \mathrm{dpm}$ of ${ }^{3} \mathrm{H}$ ). At levels near the practical detection limit, ${ }^{14} \mathrm{C}$ was overestimated by $\sim 40 \%$. Thus, at the lowest levels of radioactivity in macromolecular fractions (i.e. the DNA and protein fractions at 1 and $10 \mathrm{~min})$, the amount of ${ }^{14} \mathrm{C}$ present was overestimated. No attempt was made to correct for this bias. As discussed below, however, overestimation of the amount of ${ }^{14} \mathrm{C}$ at brief incubation times makes our interpretation of the data conservative.

Two types of control experiments determined the importance of nonbiologically incorporated radioactivity. In one experiment, long-term (300 min) and short-term ( $1 \mathrm{~min}$ ) incubations were performed on formaldehyde-killed samples to determine if adsorption of TdR to sediments contributed to the radioactivity recovered in macromolecular fractions over time. The overlying water and top $1 \mathrm{~cm}$ of sediment from six cores were removed and placed in glass jars. Two milliliters of $37 \%$ formaldehyde (stock solution) and radiolabels (same quantity as experimental cores) were added to each jar. Sediment and overlying water were assayed as described above. Radioactivity in macromolecular fractions did not change appreciably from 1 to $300 \mathrm{~min}$ (Table 1), indicating that adsorption of TdR to sediment was not responsible for the increasing amounts of radioactivity recovered in macromolecular fractions from unpoisoned sediments.

A separate experiment was performed to determine the amount of radioactivity that 


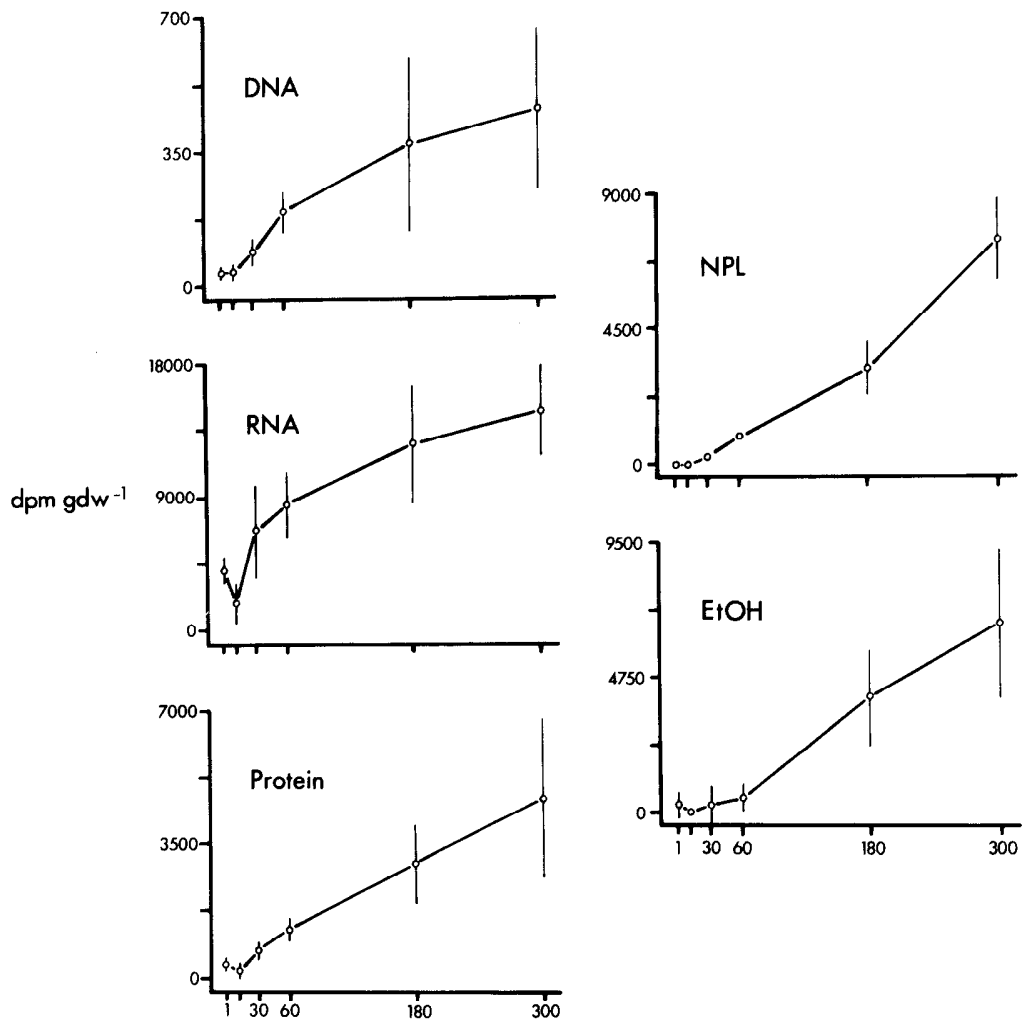

TIME $[\mathrm{MIN}]$

Fig. 2. Temporal patterns of incorporation of ${ }^{3} \mathrm{H}$ (from $\left[{ }^{3} \mathrm{H}\right] \mathrm{TdR}$ ) into fractions of TCA-insoluble material and the nonpolar-lipid fraction. Radioactivity in extraction controls (Table 1) has been subtracted. Values represent means $(n=3) \pm 1$ SD. NPL-nonpolar-lipid fraction; EtOH-ethanol washes of TCA-insoluble material.

appeared in macromolecular fractions simply as the result of the extraction procedure (i.e. without the possible confounding influence of formaldehyde). We refer to this experiment as the "extraction control." From each of three cores, the top $1 \mathrm{~cm}$ of sediment was divided in half, and radiolabeled TdR was added immediately after sediment was placed in TCA or chloroform-methanol. Macromolecular fractions were separated as above. The design of the extraction control precluded the assay of ${ }^{14} \mathrm{CO}_{2}$ in overlying water.

Data from sediment extractions were normalized to sediment weight and expressed as dpm per gram of dry weight of sediment $\left(\mathrm{dpm}\right.$ gdw $\left.{ }^{1}\right)$. Mean dpm $\mathrm{gdw}^{-1}$ in extraction controls (Table 1) was subtracted from $\mathrm{dpm} \mathrm{gdw}^{-1}$ in experimental incubations.
With two exceptions, radioactivity recovered in molecular fractions from unpoisoned-sediment incubations (Figs. 2 and 3) was much higher than radioactivity in extraction controls (Table 1). The exceptions were moderately polar and polar-lipid fractions, in which counts werc as high in cxtraction controls (Table 1) as in experimental incubations (data not shown). These fractions will not be considered further.

Data from sediment incubations were compared with those obtained from a laboratory culture of an aerobic, heterotrophic bacterial isolate from the study site. By using cells in log-phase growth (see below), the expectation was that nearly all radioactivity should have been incorporated into DNA. A dual-label mixture of $\mathrm{TdR}(17.13 \mu \mathrm{Ci}$ methyl $\left[{ }^{3} \mathrm{H}\right] \mathrm{TdR}$ and $3.54 \mu \mathrm{Ci}$ methyl 

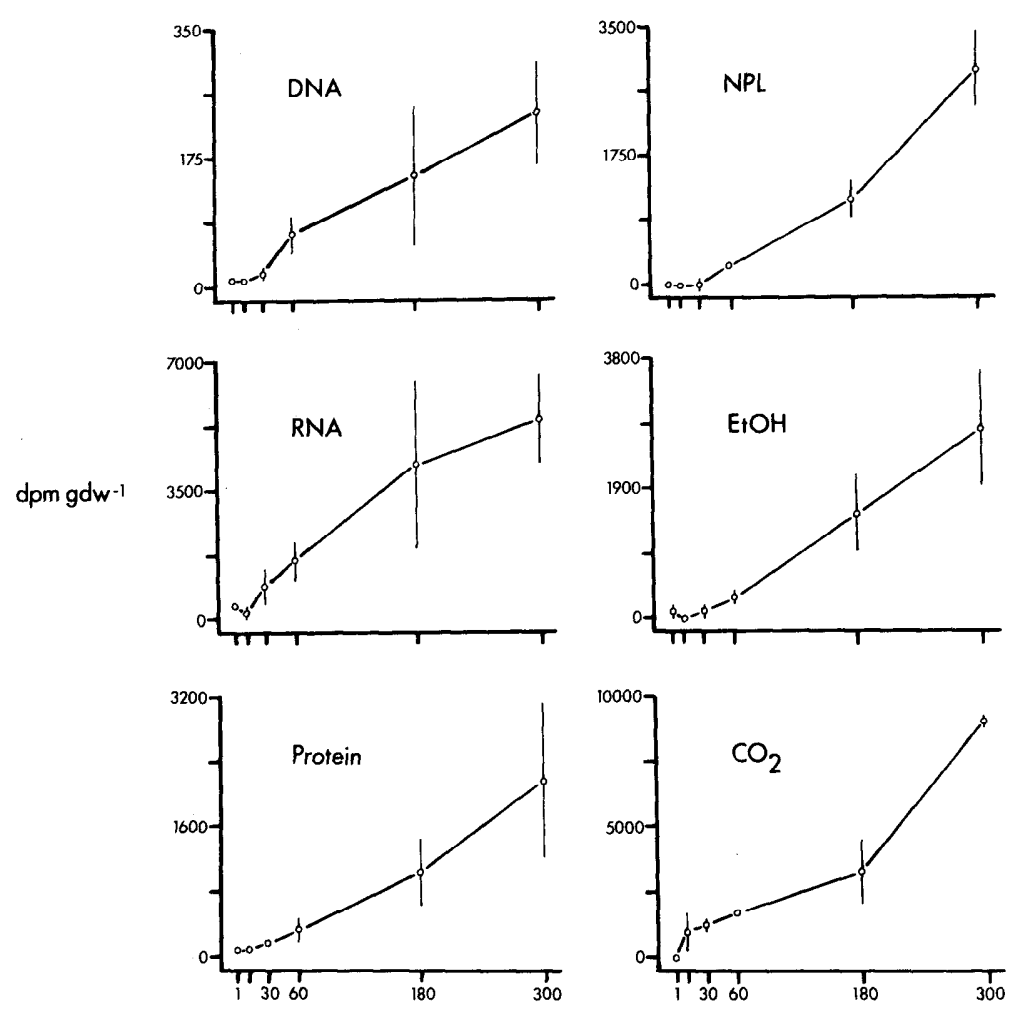

TIME [MIN]

Fig. 3. Temporal patterns of incorporation of ${ }^{14} \mathrm{C}$ (from $\left[{ }^{14} \mathrm{C}\right] \mathrm{TdR}$ ) into fractions of TCA-insoluble material, the nonpolar-lipid fraction, and $\mathrm{CO}_{2}$. Format as in Fig. 2, except the 300-min value for $\mathrm{CO}_{2}$ is based on only two replicates. $\mathrm{CO}_{2}-\mathrm{CO}_{2}$ in overlying water.

$\left.\left[{ }^{14} \mathrm{C}\right] \mathrm{TdR}\right)$ was added to a $30-\mathrm{ml}$ culture in early $\log$-phase growth $\left(\sim 2.5 \times 10^{7}\right.$ cells $\left.\mathrm{ml}^{-1}\right)$. The incubation was ended $2 \mathrm{~h}$ later $\left(\sim 4.0 \times 10^{7}\right.$ cells $\left.\mathrm{ml}^{-1}\right)$, and ninc $3-\mathrm{ml}$ subsamples were removed to test tubes. Cells were pelletized $(1,800 \times \mathrm{g}, 10 \mathrm{~min})$ and washed three times with $2.5 \% \mathrm{NaCl}$ solution. Diatomaceous earth $(0.25 \mathrm{~g})$ was added to three pellets, autoclaved sediment $(2.0 \mathrm{~g})$ from the study site was added to three pellets, and three pellets received no additions. Macromolecular fractions of TCA-insoluble material were then separated with the same procedure that was applied to sediment samples.

Results of the incubations of unpoisoned sediments are presented in Figs. 2 and 3. Data from 10-min incubations tended to deviate from otherwise consistent temporal patterns of incorporation. The anomaly in $\mathrm{dpm} \mathrm{gdw}^{-1}$ was reflected in relative incor- poration and, to a lesser degree, in ${ }^{3} \mathrm{H}:{ }^{14} \mathrm{C}$ ratios. We have no explanation for the anomalous 10-min data. When discussing temporal patterns, it is with the implicit caveat that these data may be exceptional.

Tritium (Fig. 2) and ${ }^{14} \mathrm{C}$ (Fig. 3) radioactivity in DNA, RNA, and protein fractions increased steadily with time. Relative to DNA, RNA, and protein fractions, incorporation of radioactivity into the nonpolar-lipid fraction lagged over the first three incubation periods, but increased markedly from 60 to $300 \mathrm{~min}$. A similar pattern occurred in the ethanol washes of TCA-insoluble material. Quantitatively, dpm in the nonpolar-lipid fraction were similar to dpm in ethanol washes (Figs. 2 and 3). ${ }^{14} \mathrm{CO}_{2}$ was barely detectable after $1 \mathrm{~min}, 12 \pm 7$ (mean $\pm \mathrm{SD}$ ) $\mathrm{dpm}_{\mathrm{gdw}} \mathrm{gd}^{-1}$ but rapidly increased thereafter (Fig. 3).

Of the ${ }^{3} \mathrm{H}$ accounted for in the DNA, 
RNA, and protein fractions, $2 \%$ or less was present in the DNA fraction (Fig. 4) over the range of incubation times. From 1 to $300 \mathrm{~min}$, the proportion of ${ }^{3} \mathrm{H}$ in the protein fraction increased from 8 to $23 \%$ and decreased from 91 to $75 \%$ in the RNA fraction. The proportions of ${ }^{14} \mathrm{C}$ in components of TCA-insoluble material were qualitatively and nearly quantitatively identical to those observed for ${ }^{3} \mathrm{H}$. Relative to incorporation into DNA, RNA, and protein fractions, the amount of ${ }^{14} \mathrm{C}$ appearing as ${ }^{14} \mathrm{CO}_{2}$ steadily increased with time and accounted for most (58\%) of the radioactivity after 300 min (Fig. 4).

The low percentage of radioactivity recovered in the DNA fraction could have been due, in part, to the high (micromolar) concentrations of TdR that we used. Hollibaugh (1988) found that, in general, percent incorporation of label into the DNA fraction of estuarine bacterioplankton was an inverse function of methyl $\left[{ }^{3} \mathrm{H}\right] \mathrm{TdR}$ concentration. Karl (1982), however, found greater incorporation of $2-\left[{ }^{14} \mathrm{C}\right] \mathrm{TdR}$ (at micromolar concentrations) than methyl $\left[{ }^{3} \mathrm{H}\right] \mathrm{TdR}$ (at nanomolar concentrations) into the DNA fraction of freshwater bacterioplankton. Fallon and Newell (1986) found that the incorporation rate of TdR was nonsaturable over a wide range of $\mathrm{TdR}$ concentrations $\left(10^{1}-10^{5} \mathrm{nM}\right)$. Moriarty and Pollard (1981) advocated the use of high concentrations of TdR to stop de novo synthesis of TdR. Micromolar concentrations of TdR were used in our experiment with the bacterial isolate (Table 2), and about $80 \%$ of the radioactivity in TCA-insoluble material was recovered in the DNA fraction. Thus, although TdR concentration may influence the manner in which $\mathrm{TdR}$ is used by natural assemblages of bacteria, even the direction of the relationship is unclear.

Another factor that could have influenced these results is the procedure used for separating macromolecular fractions. Moriarty (1986) referred to Munro and Fleck (1966) in contending that cold-acid precipitation followed by hot-alkaline hydrolysis degrades DNA, with the result that radioactivity recovered in the RNA fraction is partially from degraded DNA. However, Munro and Fleck clearly stated that DNA is degraded if acid-insoluble material is rinsed
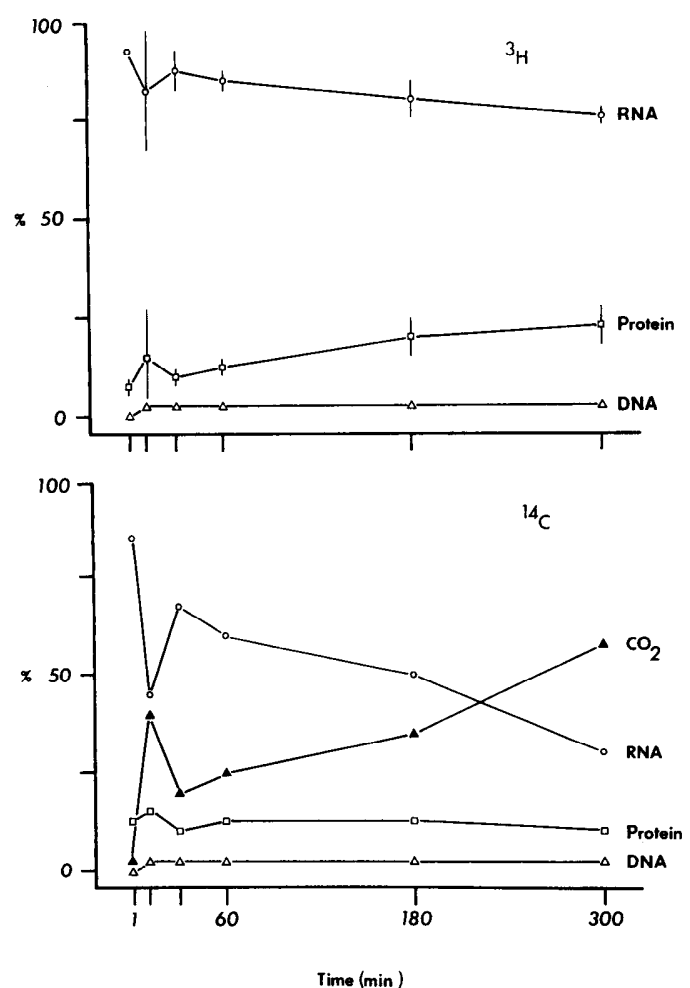

Fig. 4. Percent radioactivity in molecular fractions incubated with $\left[{ }^{3} \mathrm{H}\right] \mathrm{TdR}$ and $\left[{ }^{14} \mathrm{C}\right] \mathrm{TdR}$. Total radioactivity equals the sum of radioactivity in all components shown. Values represent means $(n=3$, except for 300 -min data for ${ }^{14} \mathrm{C}$, where $n=2$ ). Error bars on ${ }^{3} \mathrm{H}$ data are $\pm 1 \mathrm{SD}$; error bars for DNA are less than the width of the symbol. For clarity, SD is not shown for ${ }^{14} \mathrm{C}$ data, but is of the same magnitude as for ${ }^{3} \mathrm{H}$.

with hot ethanol or the alkaline hydrolysis is carried out at $100^{\circ} \mathrm{C}$. In our study, icecold ethanol was used and the hydrolysis was performed at $37^{\circ} \mathrm{C}$. Moreover, the general procedure described by Craven and Karl (1984) is consistent with the method recommended by Munro and Fleck for fractionating nucleic acids. When we used Craven and Karl's procedure to separate nucleic-acid fractions from a bacterial culturc in log-phase growth, we obtained results consistent with theoretical expectations. That is, most $(80 \%)$ of the incorporated radioactivity was recovered in the DNA fraction (Table 2). Further, recovery of radioactivity in the DNA fraction was not diminished by the presence of sediment. Karl (1982) found that the general procedure used in the present study yielded internally consistent results, but the propor- 
Table 2. Experiment to determine the pattern of labeling in macromolecular fractions of TCA-insoluble material from a bacterial culture incubated with methyl $\left[{ }^{3} \mathrm{H}\right] \mathrm{Tdr}$ and methyl $\left[{ }^{14} \mathrm{C}\right] \mathrm{TdR}$, and the effect of scdiment or diatomaceous earth on the extraction procedure. Three different treatments, each consisting of three replicates, were compared: bacteria only (B), bacteria and autoclaved sediment $(B+A S)$, bactcria and diatomaceous earth $(\mathrm{B}+\mathrm{DE})$.

\begin{tabular}{|c|c|c|c|c|c|c|c|c|}
\hline & \multicolumn{4}{|c|}{${ }^{3} \mathrm{H}$} & \multicolumn{4}{|c|}{${ }^{14} \mathrm{C}$} \\
\hline & DNA & RNA & Protein & EtOH wash & DNA & RNA & Protein & EtOH wash \\
\hline \multicolumn{9}{|c|}{ Average (SD) dpm per $3 \mathrm{ml}$ of culture in fractions of TCA-insoluble material } \\
\hline B & $\begin{array}{c}11,047 \\
(1,432)\end{array}$ & $\begin{array}{r}2,407 \\
(245)\end{array}$ & $\begin{array}{c}543 \\
(573)\end{array}$ & $\begin{array}{c}4,830 \\
(611)\end{array}$ & $\begin{array}{c}2,415 \\
(305)\end{array}$ & $\begin{array}{c}460 \\
(104)\end{array}$ & $\begin{array}{c}220 \\
(157)\end{array}$ & $\begin{array}{l}979 \\
(66)\end{array}$ \\
\hline $\mathrm{B}+\mathrm{AS}$ & $\begin{array}{l}15,186 \\
(1,061)\end{array}$ & $\begin{array}{c}1,473 \\
(255)\end{array}$ & $\begin{array}{c}1,917 \\
(427)\end{array}$ & $\begin{array}{r}991 \\
(88)\end{array}$ & $\begin{array}{r}3,340 \\
(228)\end{array}$ & $\begin{array}{l}270 \\
(35)\end{array}$ & $\begin{array}{l}403 \\
(38)\end{array}$ & $\begin{array}{l}178 \\
(36)\end{array}$ \\
\hline $\mathrm{B}+\mathrm{DE}$ & $\begin{array}{r}12,742 \\
(521)\end{array}$ & $\begin{array}{r}1,860 \\
(191)\end{array}$ & $\begin{array}{c}1,437 \\
(265)\end{array}$ & $\begin{array}{r}2,254 \\
(968)\end{array}$ & $\begin{array}{r}2,760 \\
(176)\end{array}$ & $\begin{array}{l}383 \\
(60)\end{array}$ & $\begin{array}{c}410 \\
(105)\end{array}$ & $\begin{array}{l}567 \\
(83)\end{array}$ \\
\hline \multicolumn{9}{|c|}{ Average $(\mathrm{SD})$ percent of combined dpm } \\
\hline B & $\begin{array}{l}78.9 \\
(4.6)\end{array}$ & $\begin{array}{c}17.2 \\
(1.1)\end{array}$ & $\begin{array}{c}3.8 \\
(3.8)\end{array}$ & $\begin{array}{l}- \\
-\end{array}$ & $\begin{array}{l}78.2 \\
(4.6)\end{array}$ & $\begin{array}{l}14.7 \\
(1.6)\end{array}$ & $\begin{array}{c}7.1 \\
(4.7)\end{array}$ & - \\
\hline $\mathrm{B}+\mathrm{AS}$ & $\begin{array}{l}81.8 \\
(1.9)\end{array}$ & $\begin{array}{c}7.9 \\
(0.8)\end{array}$ & $\begin{array}{l}10.3 \\
(2.1)\end{array}$ & $\begin{array}{l}- \\
-\end{array}$ & $\begin{array}{c}83.2 \\
(0.4)\end{array}$ & $\begin{array}{c}6.7 \\
(0.6)\end{array}$ & $\begin{array}{l}10.1 \\
(1.0)\end{array}$ & - \\
\hline $\mathrm{B}+\mathrm{DE}$ & $\begin{array}{l}79.4 \\
(1.8)\end{array}$ & $\begin{array}{l}11.6 \\
(1.5)\end{array}$ & $\begin{array}{c}8.9 \\
(1.6)\end{array}$ & - & $\begin{array}{l}77.7 \\
(3.8)\end{array}$ & $\begin{array}{l}10.8 \\
(1.9)\end{array}$ & $\begin{array}{l}11.5 \\
(2.7)\end{array}$ & - \\
\hline
\end{tabular}

tion of label from TdR rccovered in the DNA fraction varied according to the environment $(56-87 \%$ in coastal water; $89-$ $95 \%$ in bacterial culture; $4-6 \%$ in a freshwater pond) and with location of the label on the TdR molecule. Therefore, although it is recognized that no fractionation procedure is $100 \%$ efficient, there is no evidence that our results are artifacts of the extraction procedure used.

A considerable amount of radioactivity was recovered in the ethanol washes of TCA-insoluble material from control experiments (Table 1), the bacterial isolate (Table 2), and incubations of unpoisoned marine sediments (Figs. 2 and 3). Radioactivity in the ethanol washes from unpoisoned sediments was at least partially due to biological incorporation, as evidenced by the increasing recovery of radioactivity over time. Although ethanol washes of acid-insoluble material are recommended by some investigators (Munro and Fleck 1966; Kennell 1967; Craven and Karl 1984), they are not included in the TdR technique most commonly used (i.e. Fuhrman and Azam $1980,1982)$. Ethanol washes were originally included in the fractionation procedure to remove phospholipids from TCA-insoluble material (Munro and Fleck 1966). Robarts et al. (1986) concluded that radioactivity in the ethanol rinses of cold-TCA precipitates was due to incorporation into lipids, but later decided that this radioactivity represented unincorporated TdR (Wicks and Robarts 1987). Our data suggest that ethanol washes remove two pools of radioactivity: unincorporated, possibly adsorbed thymidine that is not removed by washes with cold TCA and biologically incorporated radioactivity equivalent to radioactivity recovered in the nonpolar-lipid fraction.

Our results underscore the importance of isolating the DNA fraction from other macromolecular fractions (as a minimum requirement) when estimating bacterial productivity of natural systems with the TdR technique (e.g. Karl 1982, 1986; Robarts et al. 1986; Servais et al. 1987; Hollibaugh 1988). In water-column studies, it is codified methodology (Parsons et al. 1984) to regard the radioactivity in the cold-TCAinsoluble fraction as being incorporated exclusively into DNA. Had we done so in this study of sediments, we would have overestimated incorporation of radioactivity into the DNA fraction by a factor of 50-100.

Use of TdR to measure bacterial growth rates in nature was pioneered by Brock (1971), who carefully stipulated the technique's assumption (p. 50) "that there is nothing intrinsically different about the way 

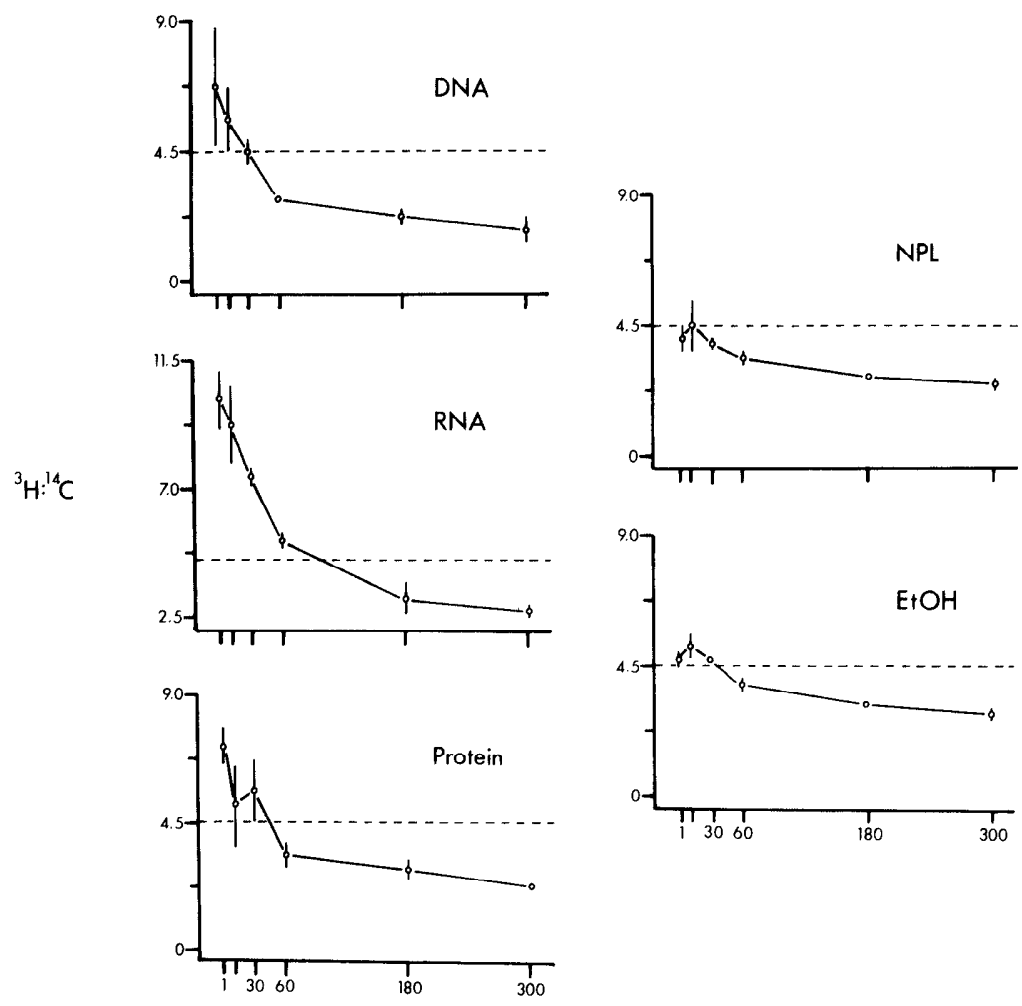

TIME [MIN]

Fig. 5. Temporal pattern of ${ }^{3} \mathrm{H}:{ }^{14} \mathrm{C}$ ratios in macromolecular fractions and the ethanol washes of TCAinsoluble material, and the nonpolar-lipid fraction. Values are means $(n=3) \pm 1 \mathrm{SD}$. Dashed lines designate the ${ }^{3} \mathrm{H}:{ }^{14} \mathrm{C}$ ratio of TdR that was added to sediment, i.e. 4.58. NPL-nonpolar-lipid fraction; EtOH-ethanol washes of TCA-insoluble material.

cultures and natural samples incorporate tritiated thymidine." Clearly our results attest to a vast difference in the metabolic fate of TdR supplied to bacteria in culture (Table 2) vs. bacteria in marine sediments (Fig. 4). Recent reports (Fallon and Newell 1986; Servais et al. 1987) have suggested that, under nutrient-limiting conditions, $\mathrm{TdR}$ is more likely to be used as a carbon and energy source than as a precursor of DNA. Most bacteria in sedimentary systems are not growing (Novitsky 1987; Carman pers. obs.), a circumstance that could be the result of nutrient limitation. We suggest, therefore, that the high degree of catabolism and nonspecific labeling observed in this study may have been due to the use of TdR as a source of carbon and energy by a nutrientlimited assemblage of sedimentary bacteria. Inspection of ${ }^{3} \mathrm{H}:{ }^{14} \mathrm{C}$ ratios in macro- molecular fractions (Fig. 5) provides insight as to how radioactivity was incorporated. If macromolecules had been labeled predominantly by proton transfer, ${ }^{3} \mathrm{H}:{ }^{14} \mathrm{C}$ ratios would have consistently been above 4.58 (the ratio at which radioactivity was added). If macromolecules had been labeled primarily by transmethylation, the ${ }^{3} \mathrm{H}:{ }^{14} \mathrm{C}$ ratio would not have changed with time. Similarly, if DNA had been labeled only by direct incorporation of TdR, the ${ }^{3} \mathrm{H}:{ }^{14} \mathrm{C}$ ratio in the DNA fraction should have been consistently around 4.58. None of these patterns was observed. Instead, at incubation times of 1 and $10 \mathrm{~min}$, the ${ }^{3} \mathrm{H}:{ }^{14} \mathrm{C}$ ratio was above 4.58 in DNA, RNA, and protein fractions. In all fractions, the ratio decreased with time to well below 4.58 at incubation times of 180 and $300 \mathrm{~min}$.

From these observations, and the result 
that at least the methyl group of TdR was extensively catabolized, we propose an explanation of the ${ }^{3} \mathrm{H}:{ }^{14} \mathrm{C}$ ratio of incorporation into macromolecular fractions: $\mathrm{Ca}$ tabolism of methyl $\left[{ }^{3} \mathrm{H}\right] \mathrm{TdR}$ results in the loss of ${ }^{3} \mathrm{H}$, chiefly as ${ }^{3} \mathrm{H}_{2} \mathrm{O}$, which has a low specific activity when mixed with the cell's internal pool of water. On the other hand, in addition to ${ }^{14} \mathrm{CO}_{2},{ }^{14} \mathrm{C}$-labeled organic products are produced as methyl $\left[{ }^{14} \mathrm{C}\right] \mathrm{TdR}$ is catabolized. If ${ }^{3} \mathrm{H}_{2} \mathrm{O}$ is released earlier in the catabolic process than ${ }^{14} \mathrm{C}$ organics, however, macromolecules would be enriched in ${ }^{3} \mathrm{H}$ after brief incubations as the result of proton transfer. Over longer incubations, ${ }^{14} \mathrm{C}$-organic molecules would be incorporated into macromolecules via anabolic pathways. In short, carbon from catabolized TdR is more likely to be conserved and recycled over time than is hydrogen. Thus, recycling of products of TdR catabolism would result in macromolecules with ${ }^{3} \mathrm{H}:{ }^{14} \mathrm{C}$ ratios that decrease with time.

The ${ }^{3} \mathrm{H}:{ }^{14} \mathrm{C}$ ratio in each macromolecular fraction did decrease with time, but the rate of decrease and absolute values of ratios differed among the various fractions (Fig. 5). These differences may reflect different rates of macromolecular synthesis and turnover or different mechanisms of incorporation. For example, ${ }^{3} \mathrm{H}:{ }^{14} \mathrm{C}$ ratios in the RNA fraction were relatively high at short incubation times and rapidly decreased thereafter. From the above argument on recycling of labels, the pattern of ratios observed in the RNA fraction would be expected for macromolecules with a relatively high rate of synthesis and turnover.

In contrast to the RNA fraction, ${ }^{3} \mathrm{H}:{ }^{14} \mathrm{C}$ ratios in the nonpolar-lipid fraction were near the "expected" value of 4.58 over incubation times from 1 to $30 \mathrm{~min}$ (Fig. 5). The ratios then decreased from 60 to 300 min. This pattern, in conjunction with the lag in incorporation over brief incubation times (Figs. 2 and 3), suggests that radioactivity in the nonpolar-lipid fraction may have been due to secondary incorporation by eucaryotes (i.e. grazing). Unlike the macromolccules DNA, RNA, and protein, relatively little nonpolar lipid is produced by bacteria (Gehron and White 1982), but it is an important storage product of eucaryotes (Benson et al. 1973). Secondary incorporation into nonpolar lipids should result in further enrichment of ${ }^{14} \mathrm{C}$ relative to ${ }^{3} \mathrm{H}$ as bacterial biomass is catabolized and resynthesized by eucaryotes. Further, the absolute values and temporal patterns of ${ }^{3} \mathrm{H}$ : ${ }^{14} \mathrm{C}$ ratios were similar in ethanol washes and the nonpolar-lipid fraction. These observations support the earlier suggestion that biologically incorporated radioactivity recovered in ethanol washes was of the same macromolecular origin as that recovered in the nonpolar-lipid fraction.

We emphasize that a time-course study was necessary to interpret the manner in which labels were recycled. For example, if only a 30-min incubation had been performed, it would have appeared that ${ }^{3} \mathrm{H}$ and ${ }^{14} \mathrm{C}$ were incorporated into DNA in the proportion they were added. The ${ }^{3} \mathrm{H}:{ }^{14} \mathrm{C}$ ratio at any given incubation time represents the transient integration of a dynamic process. The temporal pattern of ${ }^{3} \mathrm{H}:{ }^{14} \mathrm{C}$ ratios in the DNA fraction (Fig. 5) indicates that radioactivity was incorporated by recycling of labels. We suggest therefore that labeling of DNA occurred, at least partially, from recycling of products of TdR catabolism and de novo synthesis of purines and pyrimidines.

Quantitative determination of macromolccular synthesis with radiotracer techniques requires that the in situ specific activity of the labeled precursor to the macromolecule of interest is known (Karl 1986; Moriarty 1986). If radioactivity appears in DNA by de novo synthesis of purines and pyrimidines, however, the biochemical pathways of incorporation into DNA cannot be determined reliably and thus knowledge of the specific activity of dTTP is of little value.

In conclusion, we emphasize that our data emanate from studies of a coastal marine sediment, and it would be premature to generalize to other environments. Although nonspecific labeling by $\mathrm{TdR}$ has been reported from various aquatic environments, our observation of $2 \%$ incorporation into the DNA fraction is low in comparison to most other reports (but see Servais et al. 1987; Hollibaugh 1988). This result may be 
due partially to the relatively high concentrations of TdR that we used or imperfect separation of macromolecular fractions; it may also be due to the diverse physiologies of sedimentary bacteria. Our results suggest that nonspecific labeling in the environment examined is symptomatic of catabolism, which is a prerequisite for recycling of labels into all macromolecules, including DNA. Catabolism of TdR will adversely affect the accuracy of TdR-based estimates of bacterial production, even if DNA is isolated from other macromolecules.

Kevin R. Carman

Department of Oceanography

Florida State University

Tallahassee 32306-3048

Fred C. Dobbs

Marine Sciences Research Center

State University of New York at

Stony Brook

Stony Brook 11794-5000

James B. Guckert

Department of Microbiology

Montana State University

Bozeman 59717

\section{References}

Benson, A. A., R. F. Lee, and J. C. Nevenzel. 1973. Wax esters: Major marine metabolic energy sources. Biochem. Soc. Symp. 35: 75-187.

BROCK, T. D. 1971. Microbial growth rates in nature. Bact. Rev. 35: 39-58.

Craven, D. B., and D. M. Karl. 1984. Microbial RNA and DNA synthesis in marine sediments. Mar. Biol. 83: 129-139.

Fallon, R. D., AND S. Y. Newell. 1986. Thymidine incorporation by the microbial community of standing dead Spartina alterniflora. Appl. Environ. Microbiol. 52: 1206-1208.

Findlay, R. H., P. C. Pollard, D. J. W. Moriarty, AND D. C. White. 1985. Quantitative determination of microbial activity and community nutritional status in estuarine sediments: Evidence for a disturbance artifact. Can. J. Microbiol. 31: 493-498.

Findlay, S. E. G., J. L. Meyer, and R. T. Edwards. 1984. Measuring bacterial production via rate of incorporation of $\left[{ }^{3} \mathrm{H}\right]$ thymidine into DNA. J. Microb. Methods 2: 57-72.

Fuhrman, J. A., AND F. AzAm. 1980. Bacterioplankton secondary production estimates for coastal waters of British Columbia, Antarctica, and California. Appl. Environ. Microbiol. 39: 1085-1095.
- , AND - 1982. Thymidine incorporation as a measure of heterotrophic bacterioplankton production in marine surface waters: Evaluation and field results. Mar. Biol. 66: 109-120.

- $\longrightarrow$ AND OTHERS. 1986. Does adenine incorporation into nucleic acids measure total microbial production? Limnol. Oceanogr. 31: 627-636.

Gehron, M. J., AND D. C. WhIte. 1982. Quantitative determination of the nutritional status of detrital microbiota and the grazing fauna by triglyceride glycerol analysis. J. Exp. Mar. Biol. Ecol. 64: 145158.

Guckert, J. B., C. P. Antworth, P. D. Nichols, AND D. C. WhITE. 1985. Phospholipid, ester-linked fatty acid profiles as reproducible assays for changes in prokaryotic community structure of estuarine sediments. FEMS (Fed. Eur. Microbiol. Soc.) Microb. Ecol. 31: 147-158.

Hagström, А., U. Larsson, P. HöRstedt, AND S. NORMARK. 1979. Frequency of dividing cells, a new approach to the determination of bacterial growth rates in aquatic environments. Appl. Environ. Microbiol. 37: 805-823.

Hobsie, J. E., ANd C. C. CRAwford. 1969. Respiration corrections for bacterial uptake of dissolved organic compounds in natural waters. Limnol. Oceanogr. 14: 528-532.

Hollibaugh, J. T. 1988. Limitations of the $\left[{ }^{3} \mathrm{H}\right]$ thymidine method for estimating bacterial productivity due to thymidine metabolism. Mar. Ecol. Prog. Ser. 43: 19-30.

Iverson, R. L., H. F. Bittaker, ANd V. B. Myeks. 1976. Loss of radiocarbon in direct use of Aquasol for liquid scintillation counting of solutions containing ${ }^{14} \mathrm{C}-\mathrm{NaHCO}_{3}$. Limnol. Oceanogr. 21: 756-758.

KaRL, D. M. 1982. Selected nucleic acid precursors in studies of aquatic microbial ecology. Appl. Environ. Microbiol. 44: 891-902.

. 1986. Determination of in situ microbial biomass, viability, metabolism, and growth, p. 85176. In J. S. Poindexter and E. R. Leadbetter [eds.], Bacteria in nature. V. 2. Plenum.

- AND C. D. WINN. 1986. Does adenine incorporation into nucleic acids measure total microbial production?: A response to comments by "Fuhrman et al. Limnol. Oceanogr. 31: 1384-1394.

KENNELL, D. 1967. Use of filters to separate radioactivity in RNA, DNA and protein, p. 686-693. In L. Grossman and K. Moldave [eds.], Methods in enzymology. Academic.

MoriarTY, D. J. W. 1986. Measurement of bacterial growth rates in aquatic systems from rates of nucleic acid synthesis. Adv. Microb. Ecol. 9: 245280.

- , AND P. C. Pollard. 1981. DNA synthesis as a measure of bacterial productivity in seagrass sediments. Mar. Ecol. Prog. Ser. 5: 151-156.

MunRo, H. N., AND A. FleCK. 1966. The determination of nucleic acids, p. 113-176. In D. Glick [ed.], Methods of biochemical analysis. Interscience.

Novitsky, J. A. 1987. Microbial growth rates and biomass production in a marine sediment: Evi- 
dence for a very active but mostly nongrowing community. Appl. Environ. Microbiol. 53: 23682372.

Parsons, T. R., Y. Maita, and C. M. Lalli. 1984. A manual of chemical and biological methods for seawater analysis. Pergamon.

Pollard, P. C., AND D. J. W. Moriarty. 1984. Validity of the tritiated thymidine method for estimating bacterial growth rates: Measurement of isotope dilution during DNA synthesis. Appl. Environ. Microbiol. 48: 1076-1083.

RiemanN, B., J. Fuhrman, ANd F. Azam. 1982. Bacterial secondary production in freshwater measured by ${ }^{3} \mathrm{H}$-thymidine method. Microb. Ecol. 8: 101-113.

Robarts, R. D., R. J. Wicks, AND L. M. SEPHTON. 1986. Spatial and temporal variations in bacterial macromolecule labeling with $\left[\right.$ methyl $\left.-{ }^{3} \mathrm{H}\right]$ thymidine in a hypertrophic lake. Appl. Environ. Microbiol. 52: 1368-1373.
Servais, P., J. Martinez, G. Billen, AND J. VIVES-REGO. 1987. Determining $\left[{ }^{3} \mathrm{H}\right]$ thymidine incorporation into bacterioplankton DNA: Improvement of the method by DNase treatment. Appl. Environ. Microbiol. 53: 1977-1979.

White, D. C., W. M. Davis, J. S. Nickels, J. D. King, AND R. J. BobBIE. 1979. Determination of sedimentary microbial biomass by extractable lipid phosphate. Oecologia 40: 51-62.

Wicks, R. J., AND R. D. Robarts. 1987. The extraction and purification of DNA labelled with [methyl- ${ }^{3} \mathrm{H}$ ] thymidine in aquatic bacterial production studies. J. Plankton Res. 9: 1159-1 166.

Submitted: 19 October 1987 Accepted: 21 June 1988 Revised: 5 August 1988

\section{Dark production of $\mathrm{H}_{2} \mathrm{O}_{2}$ in the Sargasso Sea}

\begin{abstract}
Hydrogen peroxide is introduced into the marine environment by wet and dry deposition and is produced there by photochemical reactions. Dark production, particularly by the biota, has not been demonstrated in situ. To investigate dark $\mathrm{H}_{2} \mathrm{O}_{2}$ production, we adapted a method of measuring $\mathrm{H}_{2} \mathrm{O}_{2}$ for use in the field. The method uses the enzyme-catalyzed oxidation by $\mathrm{H}_{2} \mathrm{O}_{2}$ of hydroxyphenylpropionic acid to a fluorescent dimer; its detection limit is about 3 nM. Results of a field study in the Sargasso Sea $\left(32^{\circ} \mathrm{N}, 62^{\circ} \mathrm{W}\right)$ confirmed several general characteristics of $\mathrm{H}_{2} \mathrm{O}_{2}$ distributions - a surface maximum and a diel cycle in surface waters. Data from the Sargasso Sea also demonstrated that dark, probably biological, production was occurring at significant rates at depths of $40-60 \mathrm{~m}$.
\end{abstract}

Hydrogen peroxide occurs in surface ocean water at a concentration of about 10-

\footnotetext{
Acknowledgments

We thank R. Olson (WHOI, Chief Scientist) and the scientific and ship staff for assistance on Oceanus cruise 189 (June 1987), S. W. Chisholm (MIT) for laboratory space during parts of this project, and $\mathrm{O}$. Zafiriou (WHOI), J. Hering (MIT), and G. Jones (MIT) for critical comments during aspects of this work. Funding was provided by ONR Contract N-00014-80-C-0273 and NSF Grant OCE 83-17532.
}

200 nM (Van Baalen and Marler 1966; Zika 1984). As an important intermediate in redox processes involving oxygen, this reactive species may profoundly influence the chemistry and biological activity of the oceans, particularly through its interaction with transition metals and organic compounds. The interaction of $\mathrm{H}_{2} \mathrm{O}_{2}$ with the biota may also occur directly, for example, through a recently demonstrated activity as a chemotactic agent (Haeder 1984; Nultsch and Kumar 1984). Elucidation of the role of $\mathrm{H}_{2} \mathrm{O}_{2}$ in marine systems, however, still requires a better understanding of its distribution and dynamics.

Hydrogen peroxide in the marine environment can be introduced via wet and dry deposition (Zika et al. 1982; Thompson and Zafiriou 1983) and can originate from photochemical reactions (Cooper and Zika 1983). It can also be produced by the biota. We have recently reported on the production of $\mathrm{H}_{2} \mathrm{O}_{2}$ by a marine coccolithophorid in the dark (Palenik et al. 1987). In order to investigate the importance of biological sources of $\mathrm{H}_{2} \mathrm{O}_{2}$ in the marine environment, we adapted a method of measuring $\mathrm{H}_{2} \mathrm{O}_{2}$ 